Kong. Res. J. 2(1) : 71-80, 2015

Kongunadu Arts and Science College, Coimbatore.

\title{
SPECIES DIVERSITY, UTILIZATION AND CONSERVATION IN HOME GARDENS OF SOME RESIDENTIAL AREAS, COIMBATORE, INDIA.
}

\author{
Jamuna, S., R. Subhasree, K. Karthika, S. Paulsamy* and K. Thenmozhi. \\ Department of Botany, Kongunadu Arts and Science College, Coimbatore-641 029, Tamil Nadu, India. \\ *E-mail: paulsami@yahoo.com
}

\begin{abstract}
The present study was aimed at documenting species composition, utilization and conservation of plant species growing in home gardens of 10 residential areas of Coimbatore city, India. Household interviews and home garden surveys revealed that all the 109 plant species included in 60 families included have some economic uses or with ornamental significance. Higher number of species was herbs followed by shrubs, trees, climbers, succulent herbs, vines and sub-shrubs. The families viz., Asteraceae, Apocynaceae and Acanthaceae contributed higher number of plant species than the other families to the home gardens. The species namely, Celosia cristata, Chrysanthemum odoratum and Ocimum basilicum have registered 50\% frequency among the home gardens sampled which indicates that these species have distributed and maintained in comparatively higher number of home gardens. The home garden species are mainly under the categories of vegetables, fruits, ornamentals, economic important species and medicinal. These results further report revealed that homegardens satisfy various household needs like food, ornamentals, medicines, building material, religious and ceremonial uses.
\end{abstract}

Keywords: Home gardens, species diversity, species usage, frequency, use value.

\section{INTRODUCTION}

Home garden is generally accepted to be economically efficient, ecologically sound and biologically sustainable agroforestry system (Fernandez and Nair, 1986). It also serves as sink of carbon, thereby, playing an ecological role in the current global climate change scenario (Saha et al., 2009). Home garden maintained in many places not only to meet out the need of day to day life but also to provide ecological security to some extent. Seasonal gardens in many residential areas of developing countries offer adequate economical return to the people (Eliotcoleman, 2000). Home gardens have recently been recognized for their potential for biodiversity conservation (Raheem et al., 2008; Kabir and Webb, 2008) and for their social and cultural significance (Buchmann, 2009; Rowe, 2009). Increasing attentions have been focused on the potential of home garden to harbor genetic diversity, which is a key component of conservation efforts associated with population management (Hollingsworth et al., 2005; Lengkeek et al., 2006; Miller and Schaal, 2006).

Coimbatore is the leading industrial city in southern India, endowed with huge human population of $3,458,045$. The industrial areas, educational institutions and residential areas are maintaining home gardens almost in all parts of the city. In addition to several industries like textile mills, boundaries etc. residential areas are well designed in terms of maintaining home gardens and according to availability of the land area, the residents developed and established home gardens. People of upper economic and educated maintained their home gardens mainly with many ornamental plants and some plants of red listed categories also. Despite the well establishment of home gardens no taxonomical and ecological studies have been made so far in Coimbatore city. To address this lacuna, the present study was aimed to document the flora of the home garden and to categorize the plants into medicinal/other economical important species at different locations in Coimbatore city.

\section{MATERIALS AND METHODS}

\subsection{Study site}

A total number of 10 home gardens with different sizes located in places viz., Ganapathy, Race course, Onampalayam, Avinashi, Cheran nagar, Saravanampatti, G.N. Mills, Thudiyalur, Vadavaalli and Vinayagapuram were selected for present study.

\subsection{Species analysis}

The home gardens selected were explored for the plant species for the information on habit or life form, medicinal other economic uses, parts used. Family-wise contribution of species has also been 
enumerated. The degree of distribution of various plant species among the home gardens was determined as per the following formula:

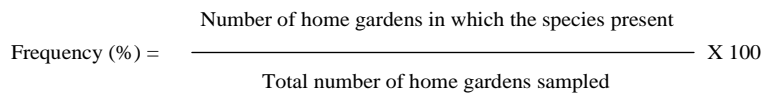

\subsection{Species usage patterns in home gardens}

The medicinal and other economic uses of the plant species present in the home gardens of sampling places were documented on the basis of personal interview with the respective gardeners and the owners of the residential homes and by literature. The red listed and endemic species were enlisted according to Ahmedullah and Nair (1987).

\section{RESULTS AND DISCUSSION}

For the present study, all over the city of Coimbatore, 10 home gardens in 10 different residential areas have been selected to enumerate the species taxonomically and to evaluate ecologically (Table 1 and Fig. 1). The sizes of the home gardens sampled were also varied much between ca. $25 \mathrm{~m}^{2}$ and $225 \mathrm{~m}^{2}$. The species richness noted to be varied between the home gardens studied. The number of species was not in accordance with the size of the home gardens studied in Coimbatore city. Studies of home gardens in Mexico (Rico Gray et al., 1991) and Indonesia (Abdoella, 2006) indicated that the number of species or individuals is not related to home garden size.

The higher species richness of 32 was present in the home gardens of Ganapathy followed by 30 in Cheran Nagar and Vinayagapuram residential areas each. On the other hand, the lower species richness of 3 was noted in the residential area of Vadavalli. Altogether, 109 plant species belongs to different life-forms were noted to be present in the studied home gardens. Kumar and Nair (2004) aptly regarded home gardens with high species richness above 20 'as the glorious examples of species diversity in cultivated and managed plant communities.

The variation in life-form among the species noted in the home garden of Coimbatore city was mostly herbs (49.54\%) followed by shrubs $(22.02 \%)$, trees $(18.35 \%)$, climbers $(3.67 \%)$, succulent herbs, vines and sub-shrub species $(1.83 \%)$. This may be due to the need and individual option. The most grown herbs in the gardens are mainly for the purpose of supplying of requirements to their day to day life as vegetables, greens and medicinal plants.
In addition to higher species diversity, the diversity of families was noted to be most noteworthy (Table 2). A total number of 60 families with the contribution 109 species were present in the home gardens. The family, Asteraceae contributed the higher number of 7 species $(11.67 \%)$ followed by the family, Apocynaceae with 6 species (10\%), Acanthaceae with 5 species (8.33\%), Moraceae, Solanaceae and Fabaceae with 4 species each (6.67\%) and Araceae, Amaranthaceae, Myrtaceae, Asparagaceae, Rubiaceae and Malvaceae with 3 species each (5\%) to the communities of home gardens. The remaining families have contributed 1 or 2 species only to home garden communities. The higher number of species in the families of Asteraceae, Apocynaceae and Acanthaceae indicates the diverse utility of the plant resources particularly the preferences towards medicinal uses. The present findings of 109 plant species belong to various life-form categories with different utilities indicate the biological richness of home gardens in Coimbatore city (Kumar et al., 1994). The high floristic diversity is perhaps the reflection of the potential of home gardens to serve as repositories of genetic diversity as well. Kabir and Webb (2008) also reported the predominance of herbs and trees in the home gardens of southwestern Bangladesh.

The degree of distribution of the various enumerated plant species was very low and it was ranging between 10 and $50 \%$ only (Table 1 ). The species namely, Celosia cristata, Chrysanthemum odoratum and Ocimum basilicum have registered $50 \%$ frequency which indicates that these species have distributed comparatively in higher number of home gardens (Fig. 2). The other species have recorded below $50 \%$ frequency only and hence they have restricted in distribution in few home gardens only. The overall distribution level indicates that each home garden owner has their own preference over the species. Pandey et al. (2006) also reported the lower distribution level of many home garden plants in South Andaman and he explained that the selective cultivation of species with the home gardens is mainly due to the utility value of the species.

The total number of individuals maintained for the constituent species in the home gardens was widely varied (Table 1 and Figs. 3 and 4). Few species like Calliandra cyanometroides, Canna indica, Catharanthus roseus, Chrysanthemum odoratum, Cosmos bipinnatus and Coriandrum sativum were registered with higher density when compared to other species (Fig. 3). The endemic plant species, Saraca indica was represented by only one 
individual at Vinayagapuram residential area. Similarly, the species such as Artocarpus heterophyllus, Callistemon citrinus, Cereus pterognus, Hamelia patens, Mangifera indica, Momordica charantia, Ravenala madagascariensis, Robinia pseudoacia, Salvinia officinalis, Scindapsus variegate, Saraca indica and Thuja mysorensis have also been represented by only one individual in very less number (Fig. 4). It has been recognized that most of the mentioned above are economically important. The maintenance of this species with higher standing crop individuals in the home gardens may be due to economic security provided by these species to the respective home.

Table 1. Number of individuals of constituent plant species and their frequency in the sampled home gardens of sampling places in Coimbatore city.

\begin{tabular}{|c|c|c|c|c|c|c|c|c|c|c|c|c|c|}
\hline \multirow{2}{*}{ S.No } & \multirow{2}{*}{ Species } & \multirow{2}{*}{ Habit } & \multicolumn{10}{|c|}{ Home gardens* } & \multirow{2}{*}{$\begin{array}{c}\text { Frequency } \\
\text { (\%) }\end{array}$} \\
\hline & & & 1 & 2 & 3 & 4 & 5 & 6 & 7 & 8 & 9 & 10 & \\
\hline 1 & Acalypha wilkesiana hort. & Shrub & 5 & 8 & - & - & 4 & - & - & - & - & - & 30 \\
\hline 2 & $\begin{array}{l}\text { Adenium obesum (Forsk.) Roem. et } \\
\text { Schult. }\end{array}$ & Shrub & 1 & - & 3 & - & 4 & - & - & - & 6 & - & 40 \\
\hline 3 & Anthurium spathiphyllum Schott & Herb & 7 & - & - & - & - & 5 & - & 6 & - & - & 30 \\
\hline 4 & Allamanda cathartica $\mathrm{L}$. & Shrub & 3 & - & - & - & - & 1 & - & - & - & - & 20 \\
\hline 5 & Aloe vera (L.) Burm.f. & $\begin{array}{l}\text { Succulent } \\
\text { nerb }\end{array}$ & - & - & - & - & - & - & 5 & - & 2 & - & 20 \\
\hline 6 & Antigonon leptopus Hook \& Arn & Vine & - & - & - & - & - & - & 17 & - & - & 25 & 20 \\
\hline 7 & Aphelandra squarrosa Nees. & Herb & - & - & - & - & - & - & - & - & - & 6 & 10 \\
\hline 8 & Aralia sp. L & Herb & - & - & - & - & - & - & 9 & - & - & - & 10 \\
\hline 9 & Arctotis hirsuta (Harv.) Beauverd & Herb & - & - & 12 & - & - & - & - & - & 6 & 8 & 30 \\
\hline 10 & Araucaria excelsa $\mathrm{R} \cdot \mathrm{Br}$ & Tree & - & - & - & 2 & - & 5 & - & - & - & - & 20 \\
\hline 11 & Achyranthes aspera L. & Herb & - & - & - & - & 23 & - & - & - & - & - & 10 \\
\hline 12 & A. caudatus $\mathrm{L}$. & Herb & - & - & - & - & - & - & - & - & - & 24 & 10 \\
\hline 13 & Azardica indica A. Juss & Tree & 1 & - & - & - & - & - & - & - & 1 & - & 20 \\
\hline 14 & Artocarpus heterophyllus Frost. & Tree & 1 & - & 1 & - & - & - & 1 & - & - & - & 30 \\
\hline 15 & Basella rubra $\mathrm{L}$. & Vine & 9 & - & - & - & - & - & - & - & - & - & 10 \\
\hline 16 & Bougainvillea glabra Choisy & Creeper & 2 & - & - & - & 3 & - & - & - & - & - & 20 \\
\hline 17 & Callistemon citrinus (Curtis) Skeels & Shrub & - & - & - & - & - & 1 & - & - & - & - & 10 \\
\hline 18 & Calliandra cyanometroides Bedd & Herb & - & - & - & - & 30 & 11 & - & 16 & 10 & - & 40 \\
\hline 19 & Calathea sp. R.Br & Herb & - & - & - & - & - & 5 & & - & - & - & 10 \\
\hline 20 & Canna indica $\mathrm{L}$. & Herb & - & - & - & - & 15 & - & - & 21 & 10 & 5 & 40 \\
\hline 21 & Capsicum anпиuт L. & Shrub & - & 3 & - & - & - & - & - & - & 2 & - & 20 \\
\hline 22 & Catharanthus roseus Linn. & Sub shrub & 18 & - & - & - & 12 & - & - & 15 & - & 10 & 40 \\
\hline 23 & Celosia cristata L. & Shrub & 2 & - & 1 & 3 & - & - & - & 5 & 2 & - & 50 \\
\hline 24 & Cereus pterogonus Lem. & Herb & - & - & - & - & - & - & - & 1 & - & - & 10 \\
\hline 25 & Cestrum nocturnum L. & Herb & - & - & - & - & - & - & 29 & - & - & - & 10 \\
\hline 26 & Chlorophytum variegatum Ker & Herb & 4 & - & - & 7 & - & - & - & 10 & 2 & - & 40 \\
\hline 27 & Chrysanthemum carinatum L & Herb & - & - & 3 & - & - & - & - & 7 & - & - & 20 \\
\hline 28 & C. grandiflorum $\mathrm{L}$. & Herb & - & 21 & - & - & - & - & - & - & - & - & 10 \\
\hline 29 & C. odoratum $\mathrm{L}$. & Herb & 70 & - & 41 & 55 & 63 & - & - & - & 84 & - & 50 \\
\hline 30 & Clitoria ternatea $\mathrm{L}$. & Herb & - & - & - & - & - & 25 & - & - & - & - & 10 \\
\hline 31 & Coleus aromaticus Benth & Herb & - & 20 & - & 6 & 9 & - & - & - & - & - & 30 \\
\hline 32 & Cordyline stricta L. & Herb & - & - & - & 6 & - & - & - & - & - & - & 10 \\
\hline 33 & Cosmos bipinnatus Cav & Herb & 63 & - & - & - & - & - & - & - & - & 82 & 20 \\
\hline 34 & Crassula sp.L. & Herb & - & - & 5 & - & - & 8 & - & - & - & - & 20 \\
\hline 35 & Crossandra infundibuliformis L Salib & Herb & 18 & - & 10 & - & - & - & - & - & 7 & - & 30 \\
\hline 36 & Cucumis pepo DC. & Climber & - & - & - & - & - & 3 & - & - & - & - & 10 \\
\hline 37 & Curcuma longa L. & Herb & 2 & - & 5 & - & - & - & - & - & - & - & 20 \\
\hline 38 & Calotropis gigantea $\mathrm{R} . \mathrm{Br}$. & Shrub & - & - & - & - & - & - & 2 & - & - & - & 10 \\
\hline 39 & Carica papaya $\mathrm{L}$. & Tree & - & - & - & - & 1 & - & - & 1 & - & - & 20 \\
\hline 40 & Coriandrum sativum Linn. & Herb & 35 & - & - & - & - & 19 & - & - & 28 & - & 30 \\
\hline 41 & Citrus lemon L. & Tree & 1 & - & - & - & 3 & - & 5 & - & - & - & 30 \\
\hline 42 & Cardiospermum halicacabum L & Herb & - & - & - & - & 5 & - & - & - & - & - & 10 \\
\hline 43 & Cycas siamensis Miq & Tree & 1 & 2 & 1 & - & - & 1 & 6 & - & - & - & 50 \\
\hline 44 & Dracaena sp. Lam & Shrub & - & - & - & - & 5 & - & 2 & - & - & - & 20 \\
\hline 45 & Duranta repens L. & Shrub & - & - & - & - & - & - & 4 & - & - & 6 & 20 \\
\hline 46 & Damascus carota Nayeem Ket & Herb & 4 & - & - & - & - & - & 2 & - & - & - & 20 \\
\hline 47 & Ficus benghalensis Linn. & Tree & - & - & - & - & - & 1 & 1 & - & - & - & 20 \\
\hline 48 & F. benjamina Linn. & Tree & 1 & - & 2 & - & - & - & - & - & - & - & 20 \\
\hline 49 & F. microspora Wight & Tree & - & - & 4 & - & - & 3 & - & - & - & - & 20 \\
\hline
\end{tabular}




\begin{tabular}{|c|c|c|c|c|c|c|c|c|c|c|c|c|c|}
\hline 50 & Geranium domesticum Roxb. & Herb & - & - & - & - & - & 2 & 5 & 6 & - & - & 30 \\
\hline 51 & G. peltatum Roxb & Herb & - & - & - & - & - & - & - & 5 & - & - & 10 \\
\hline 52 & Grevillea robusta A. Cunn. ex R. Br & Shrub & 2 & - & - & - & - & - & - & - & - & - & 10 \\
\hline 53 & Hamelia patens Jacq & Shrub & - & - & - & - & - & - & - & 1 & - & - & 10 \\
\hline 54 & Hibiscus rosa sinensis L. & Shrub & - & - & - & - & 6 & - & - & 8 & - & 9 & 30 \\
\hline 55 & H. mutabilis L. & Shrub & - & 8 & - & - & 4 & 6 & - & 2 & - & - & 40 \\
\hline 56 & H. syriacus L. & Shrub & 2 & - & - & - & - & - & - & - & - & 2 & 20 \\
\hline 57 & Hydrangea macrophylla (Thunb.) Ser. & Shrub & - & - & - & - & - & - & - & - & 2 & - & 10 \\
\hline 58 & Inga cyanocetroides Linn. & Shrub & 4 & - & 2 & - & 1 & - & - & - & 3 & - & 40 \\
\hline 59 & Ixora coccinea $\mathrm{L}$. & Shrub & 1 & - & - & - & 4 & 4 & - & - & - & - & 30 \\
\hline 60 & Jacquemontia pentantha Choisy & Herb & - & - & - & - & 37 & - & - & - & - & - & 10 \\
\hline 61 & Jasminum angustifolium Vahl & Herb & - & - & - & - & - & 3 & - & 2 & - & - & 20 \\
\hline 62 & J. grandiflorum L & Herb & - & - & - & - & - & 2 & 1 & 1 & - & 1 & 40 \\
\hline 63 & J. sambac Ait & Herb & - & - & - & - & 2 & - & - & - & - & 3 & 20 \\
\hline 64 & Jatropha peltata Wight & Herb & - & - & - & - & - & - & - & - & - & 2 & 10 \\
\hline 65 & Kalanchoe fentchokoi Adans & Herb & - & - & 10 & - & - & - & - & - & - & 14 & 20 \\
\hline 66 & Knoxia sp. L. & Herb & - & - & - & - & - & - & - & 20 & 16 & - & 20 \\
\hline 67 & Lablab purpureus (L) Sweet & Vine & - & - & 3 & - & - & - & 1 & 2 & 4 & - & 40 \\
\hline 68 & Lantana viscose $\mathrm{L}$. & Shrub & 1 & - & - & - & - & - & - & 1 & - & - & 20 \\
\hline 69 & Lawsonia inermis L. & Tree & - & - & - & - & - & - & - & 1 & - & 1 & 20 \\
\hline 70 & Madhuca longifolia J. Konig J.F.Macbr. & Tree & - & - & - & - & - & - & - & 2 & 1 & 2 & 30 \\
\hline 71 & Mangifera indica $\mathrm{L}$. & Tree & - & - & - & - & - & - & - & - & 1 & - & 10 \\
\hline 72 & Miranda leucophyllum Harts & Tree & 7 & - & - & - & - & - & - & - & - & - & 10 \\
\hline 73 & Momordica charantia L. & Herb & - & - & - & 1 & - & - & - & - & - & - & 10 \\
\hline 74 & Moringa oleofera Lam & Tree & - & - & - & - & 2 & - & - & - & - & - & 10 \\
\hline 75 & Murraya paniculata L. & Herb & - & - & - & - & 4 & - & - & 2 & - & - & 20 \\
\hline 76 & Musa paradisiaca L. & Tree & - & - & - & - & - & 1 & 4 & 5 & - & - & 30 \\
\hline 77 & Nephrolepis sp. Schot & Herb & - & - & - & - & - & - & - & - & - & 5 & 10 \\
\hline 78 & N. tuberosa Bory ex Willd & Herb & - & - & 1 & - & - & - & - & - & - & 6 & 20 \\
\hline 79 & Nerium oleander Linn. & Shrub & - & - & - & - & - & - & 3 & - & 2 & - & 20 \\
\hline 80 & Ocimum basilicum Linn. & Herb & - & - & - & 5 & 4 & 4 & 3 & 2 & - & - & 50 \\
\hline 81 & Oxalis radicosa Linn. & Herb & - & - & - & - & - & - & - & - & - & 42 & 10 \\
\hline 82 & O. corniculata Linn. & Herb & - & - & - & 37 & - & - & - & - & - & - & 10 \\
\hline 83 & Phyllanthus emblica Linn. & Tree & - & - & - & - & 1 & - & 1 & - & 1 & - & 30 \\
\hline 84 & Pistia stratiotes Linn. & $\begin{array}{l}\text { Succulent } \\
\text { nerb }\end{array}$ & - & - & - & - & - & - & 10 & - & - & 22 & 20 \\
\hline 85 & Plumbago auriculata Lam & Herb & - & - & 3 & - & - & - & - & 10 & 3 & 1 & 40 \\
\hline 86 & Plumeria rubra Linn. & Shrub & 2 & - & - & - & 1 & - & - & - & - & - & 20 \\
\hline 87 & Punica granatum Linn. & Sub shrub & - & - & - & 3 & 2 & - & 1 & - & - & 3 & 40 \\
\hline 88 & Piper betle Linn. & Creeper & - & - & - & - & - & - & - & - & 15 & 10 & 20 \\
\hline 89 & Ravenala madagascariensis Sonn & Herb & - & - & 1 & - & - & - & - & - & - & - & 10 \\
\hline 90 & Robinia pseudoacacia L. & Herb & - & - & - & - & - & 1 & - & - & - & - & 10 \\
\hline 91 & Tiarella grandiflora Roxb & Herb & 1 & - & - & - & - & - & - & - & - & - & 10 \\
\hline 92 & Rosa sp.W. & Shrub & 1 & - & 4 & - & - & - & - & - & 3 & 1 & 40 \\
\hline 93 & Salvinia officinalis L. & Herb & - & - & - & - & - & - & - & - & 1 & - & 10 \\
\hline 94 & Sansevieria roxburghiana Schult & Herb & - & - & - & - & - & - & - & - & - & 2 & 10 \\
\hline 95 & $\begin{array}{l}\text { Scindapsus variegate (Hayata) } \\
\text { Kanehira }\end{array}$ & Creeper & 1 & - & - & - & - & - & - & - & - & - & 10 \\
\hline 96 & S. melongena Pr. & Herb & - & - & - & - & 1 & - & 3 & - & 2 & - & 30 \\
\hline 97 & S. lycopersicum Linn. & Herb & - & - & - & 5 & - & - & - & - & - & - & 10 \\
\hline 98 & Saraca indica Linn. & Tree & - & - & - & - & - & - & - & - & - & 1 & 10 \\
\hline 99 & Tagetes erecta $\mathrm{B}$. & Herb & - & - & - & - & - & 1 & - & - & 2 & 3 & 30 \\
\hline 100 & Tradescantia discolor S.W & Herb & - & - & - & - & 10 & - & - & - & - & - & 10 \\
\hline 101 & Thuja occidentalis L. & Shrub & - & - & - & - & 1 & - & - & 1 & - & 1 & 30 \\
\hline 102 & T. mysorensis T. and Roxb & Shrub & 1 & - & - & - & - & - & - & - & - & - & 10 \\
\hline 103 & $\begin{array}{l}\text { Tabernaemontana divaricata R.Br. ex } \\
\text { Koem. \& Schult. }\end{array}$ & Shrub & 4 & - & - & - & - & 5 & 1 & 1 & - & - & 40 \\
\hline 104 & Tecoma grandis L.f & Tree & - & - & - & - & 1 & 2 & - & - & - & 2 & 30 \\
\hline 105 & Terminalia catappa Linn. & Tree & - & - & - & - & - & 1 & - & - & - & 1 & 20 \\
\hline 106 & Taxus wallichiana Linn & Tree & - & - & - & - & 2 & 1 & - & - & - & 1 & 30 \\
\hline 107 & Ursinia cerevisiae (Thunb.) N.E.Br & Herb & - & - & - & - & 1 & - & - & - & 2 & 1 & 30 \\
\hline 108 & Zephyranthes carinata Herb & Herb & - & - & - & - & 20 & 12 & - & - & - & - & 20 \\
\hline 109 & Zinnia grandiflora Linn. & Herb & - & - & - & 6 & - & - & 2 & - & 4 & - & 30 \\
\hline
\end{tabular}

*1 - Ganapathy; 2 - Race course; 3 - Onampalayam; 4 - Avinashi; 5 - Cheran nagar; 6 - Saravanampatti; 7 - G.N. Mills; 8 - Thudiyalur; 9 Vadavaalli; 10 - Vinayagapuram. 


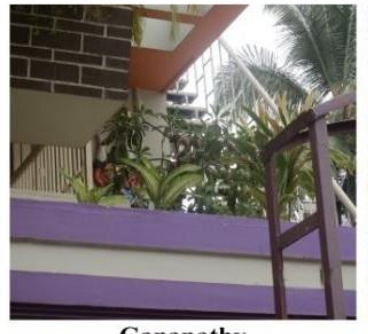

Ganapathy

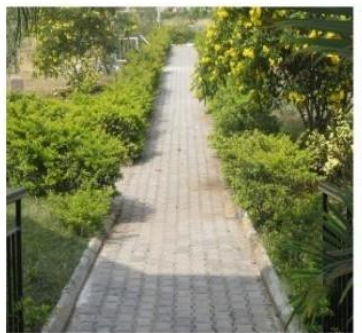

Uppilipalayam

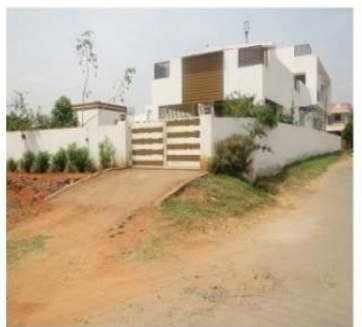

G.N. Mills

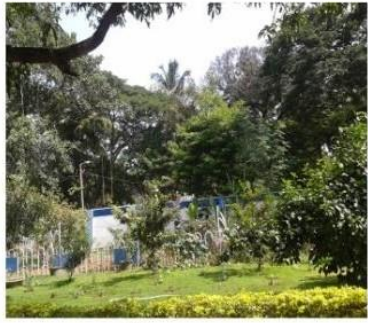
Race course

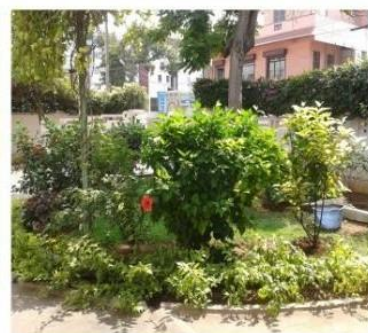

Cheran Nagar
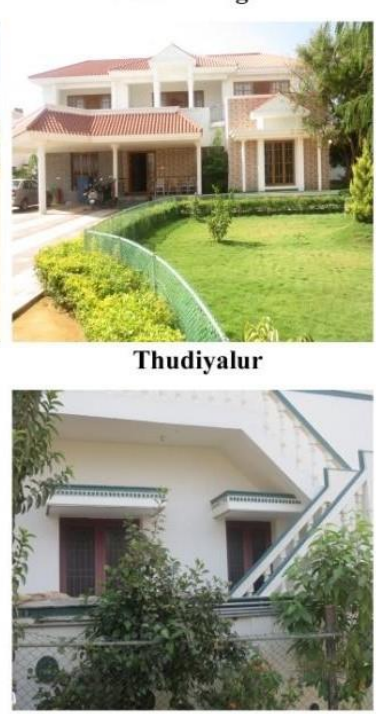

Vinayagapuram

Fig. 1. The sampled home gardens of Coimbatore city.

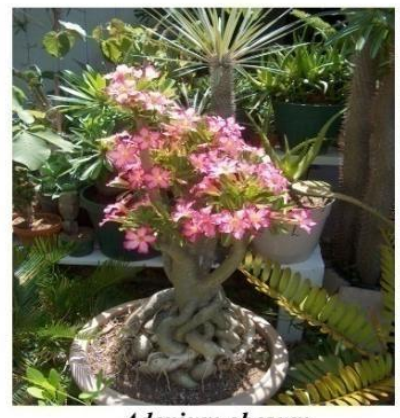

Adenium obesum

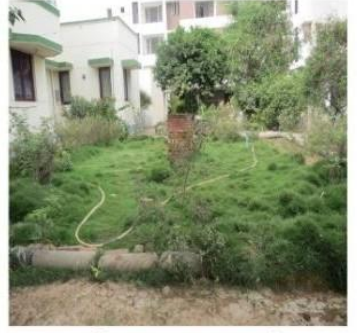

Saravanampatti

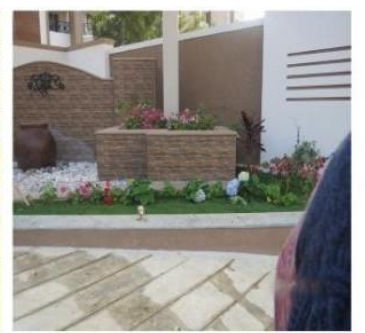

Vadavalli

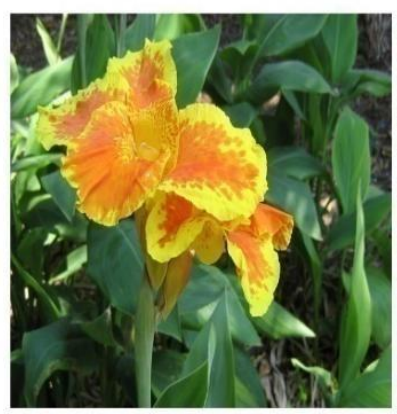

Canna indica

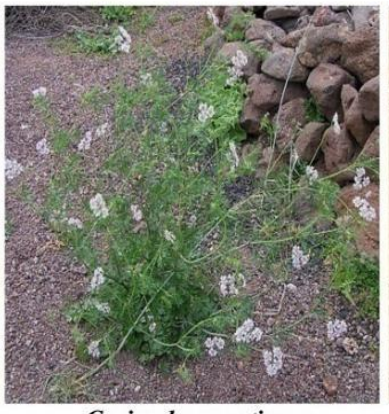

Coriandrum sativum

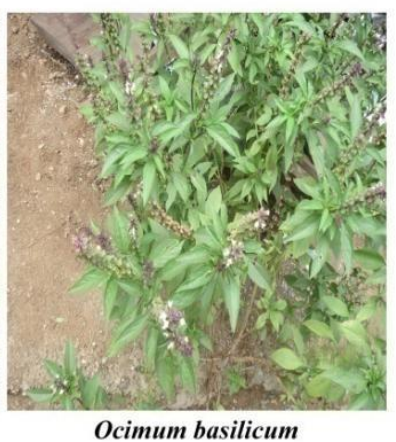

Ocimum basilicum

Fig. 2. The species of higher degree of distribution among the home gardens.

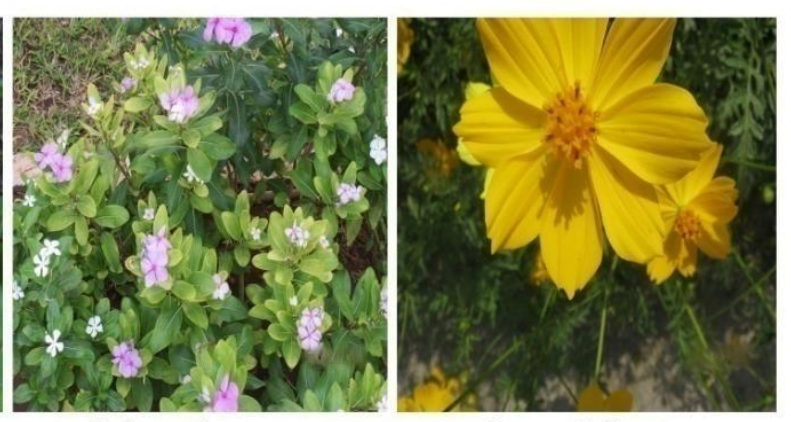

Catharanthus roseus

Cosmos bipinnatus
Fig. 3. Some species of relatively high density.

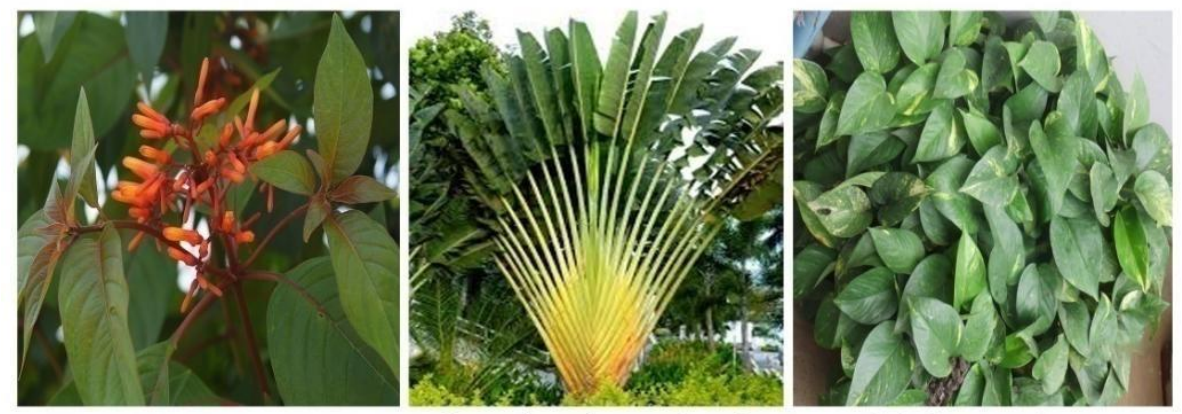

Hamelia patens
Scindapsus variegata

Fig. 4. Certain species of relatively low density. 
Table 2. Family, useful part, medicinal and other economic uses of various plant species in the home gardens of Coimbatore city.

\begin{tabular}{|c|c|c|c|c|}
\hline $\begin{array}{l}\text { S. } \\
\text { No. }\end{array}$ & Species & Family & $\begin{array}{l}\text { Parts } \\
\text { used }\end{array}$ & Medicinal/other economic uses \\
\hline 1 & $\begin{array}{l}\text { Acalypha } \\
\text { wilkesiana }\end{array}$ & Acanthaceae & Leaf & $\begin{array}{l}\text { The extract of the flower inhibits the ovarian function and stimulate } \\
\text { the uterine. Roots are used in the treatment of diabetes, antipyretic, } \\
\text { abortifacient, demulcent, lessens inflammation and heat of the body; } \\
\text { useful to relieve chest pain. }\end{array}$ \\
\hline 2 & Adenium obesum & Apocynaceae & Bark and & \\
\hline 3 & $\begin{array}{l}\text { Anthurium } \\
\text { spathiphyllum }\end{array}$ & Araceae & $\begin{array}{l}\text { Shap } \\
\text { plant }\end{array}$ & $\begin{array}{l}\text { Cleans indoor air of many environmental contaminants, including } \\
\text { benzene, formaldehyde and other pollutants. }\end{array}$ \\
\hline 4 & $\begin{array}{l}\text { Allamanda } \\
\text { cathartica }\end{array}$ & Apocynaceae & Flower & $\begin{array}{l}\text { Flower has been used to treat liver tumors, jaundice, splenomegaly and } \\
\text { malaria. }\end{array}$ \\
\hline 5 & Aloe vera & Liliaceae & Leaf & $\begin{array}{l}\text { Aloe has been marketed as a remedy for coughs, wounds, ulcers, } \\
\text { gastritis, diabetes, cancer, headaches, arthritis, immune-system } \\
\text { deficiencies, and many other conditions when taken internally. The } \\
\text { lower leaf is sliced open, the gel obtained can be applied on the } \\
\text { affected area of the skin. }\end{array}$ \\
\hline 6 & Antigonon leptopus & Polygonaceae & $\begin{array}{l}\text { Leaf, bark } \\
\text { and seed }\end{array}$ & $\begin{array}{l}\text { The leaves and barks are protective against bronchial asthma and } \\
\text { other allergic disorders. Barks and seeds are astringent and are given } \\
\text { in piles and diarrhoea. }\end{array}$ \\
\hline 7 & $\begin{array}{l}\text { Aphelandra } \\
\text { squarrosa }\end{array}$ & Acanthaceae & - & Ornamental plant. \\
\hline 8 & Aralia sp. & Araliaceae & - & Ornamental plant. \\
\hline 9 & Arctotis hirsuta & Acanthaceae & - & Ornamental plant. \\
\hline 10 & Araucaria excelsa & Araucariaceae & Leaf & It reduces the bacterial contaminants. \\
\hline 11 & Achyranthes aspera & Amaranthaceae & $\begin{array}{l}\text { Leaf and } \\
\text { seed }\end{array}$ & $\begin{array}{l}\text { It is used to improve appetite and to cure various types of gastric } \\
\text { disorders. It is useful in haemorrhoids, leaves and seeds are emetic, } \\
\text { hydrophobia, carminative, resolve swelling, digestive and expel } \\
\text { phlegm. }\end{array}$ \\
\hline 12 & A. caudatus & Amaranthaceae & $\begin{array}{l}\text { Leaf, stem } \\
\text { and root }\end{array}$ & $\begin{array}{l}\text { The roots are used to cure kidney stones. The leaves used to cure cuts, } \\
\text { leprosy, boils, burns, fever and decoction of the stem used in jaundice. } \\
\text { Leaves, bark, flowers, fruits, seed, gum, oil and neem cake are used to }\end{array}$ \\
\hline 13 & $\begin{array}{l}\text { Artocarpus } \\
\text { heterophyllus }\end{array}$ & Meliaceae & $\begin{array}{l}\text { Whole } \\
\text { plant }\end{array}$ & $\begin{array}{l}\text { have antiallergenic, antidermatic, antifeedent, antifungal, } \\
\text { antiinflammatory, antipyorrhoeic, antiscabic, cardiotonic, diuretic, } \\
\text { insecticidal, larvicidal, nematicidal, spermicidal and other biological } \\
\text { activities. }\end{array}$ \\
\hline 14 & Azardirachta indica & Moraceae & $\begin{array}{l}\text { Leaf and } \\
\text { fruit }\end{array}$ & $\begin{array}{l}\text { The leaves are useful in fever, ulcers, boils wounds, skin diseases, } \\
\text { antidiarrhoeal, analgesic and as immuno modulator. The ripe fruits are } \\
\text { sweet cooling, laxative, aphrodisiac, and tonic. The seeds used for are } \\
\text { sweet, diuretic, aphrodisiac and constipation. }\end{array}$ \\
\hline 15 & Basella rubra & Basellaceae & Root & $\begin{array}{l}\text { Decoction of the root relieves bilious vomiting. Spinach extracts has } \\
\text { beneficial effects such as chemo and central nervous system } \\
\text { protection, anticancer and antiaging function. }\end{array}$ \\
\hline 16 & $\begin{array}{l}\text { Bougainvillea } \\
\text { glabra }\end{array}$ & Nyctaginaceae & Flower & $\begin{array}{l}\text { The leaves used for a variety of disorders such as diarrhoea, and to } \\
\text { reduce stomach ulcers, cough, sore throat, hepatitis, a decoction of } \\
\text { dried stems and flower used as treatment for low blood pressure. }\end{array}$ \\
\hline 17 & Callistemon citrinus & Myrtaceae & Leaf & It is used for treating hemorrhoids. \\
\hline 18 & $\begin{array}{l}\text { Calliandra } \\
\text { cyanometroides }\end{array}$ & ceae & - & Ornamental plant. \\
\hline 19 & Calathea sp. & Marantaceae & & Ornamental plant. \\
\hline 20 & Canna indica & Cannaceae & $\begin{array}{l}\text { Root and } \\
\text { seed. }\end{array}$ & $\begin{array}{l}\text { The root decoction is used for the treatment of fever, dropsy, and } \\
\text { dyspepsia. Seed juice is used to relieve ear aches. } \\
\text { It is used as carminative, an appetizer and a stomachic. Externally, it is }\end{array}$ \\
\hline 21 & Capsicum annuum & Solanaceae & Fruit & $\begin{array}{l}\text { used as a counter irritant and also in the treatment of rheumatism, } \\
\text { lumbago and neuralgia. }\end{array}$ \\
\hline 22 & $\begin{array}{l}\text { Catharanthus } \\
\text { roseus }\end{array}$ & Apocynaceae & $\begin{array}{l}\text { Whole } \\
\text { plant }\end{array}$ & $\begin{array}{l}\text { Minimizing the adverse effects of cheamotheraphy, caricinogenic } \\
\text { agents and prolonging longevity types possesses known antibacterial, } \\
\text { antifungal, antidiabetic and antiviral activities. }\end{array}$ \\
\hline 23 & Celosia cristata & Amaranthaceae & $\begin{array}{l}\text { Leaf and } \\
\text { flower }\end{array}$ & $\begin{array}{l}\text { It is used in the treatment of diarrhoea, piles, bleeding nose, } \\
\text { disinfectant, inflammation, haematological and gynaecologic disorders. } \\
\text { Ornamental plant. }\end{array}$ \\
\hline 25 & Cestrum nocturnum & Solanaceae & Leaf & $\begin{array}{l}\text { Leaves are used for their pharmacological significance in burns and } \\
\text { swellings. It is also used for treating epilepsy and as stupefying charm } \\
\text { medicine. It is used to prevent malaria. }\end{array}$ \\
\hline 26 & $\begin{array}{l}\text { Chlorophytum } \\
\text { variegatum }\end{array}$ & Liliaceae & - & Ornamental plant. \\
\hline 27 & Chrysanthemum & Asteraceae & Flower & The leaves are used medicinally to cure influenza symptoms, liver and \\
\hline
\end{tabular}




\begin{tabular}{|c|c|c|c|c|}
\hline & carinatum & & & $\begin{array}{l}\text { menstrual disorders and have antiinflammatory and antispasmodic } \\
\text { effects. }\end{array}$ \\
\hline 28 & C. grandiflorum & Asteraceae & Leaf & It is used for anticancer activity. \\
\hline 29 & C. odoratum & Asteraceae & Flower & $\begin{array}{l}\text { Flowers are used for antihypertensive, hypertropic scar fibroblast } \\
\text { inhibiting, antidepressive, serotonin antagonist, anticancer, } \\
\text { antispasmodic, antioxidative and antimicrobial activities roselle can } \\
\text { prevent cancer and lower blood pressure as well as improve the } \\
\text { digestive system in human }\end{array}$ \\
\hline 30 & Clitoria ternatea & Fabaceae & $\begin{array}{r}\text { Whole } \\
\text { plant }\end{array}$ & $\begin{array}{l}\text { The herb is effective in curing fever and acts as asthma and bronchitis } \\
\text { etc. The extract gives neuropharmacological value. A paste of the } \\
\text { whole plant can be applied over the infected area and decoction of the } \\
\text { plants is very effective in cleaning the wound. }\end{array}$ \\
\hline 31 & Coleus aromaticus & Lamiaceae & Leaf & $\begin{array}{l}\text { The leaves are used for the treatment of cough, throat infection and } \\
\text { nasal congestion. }\end{array}$ \\
\hline 32 & Cordyline stricta & Asparagaceae & Leaf & $\begin{array}{l}\text { It is used to treat dysentery and skin diseases. It breaks fever and to } \\
\text { assuage headache. The leaves consumed as vegetable. }\end{array}$ \\
\hline 33 & Cosmos bipinnatus & Asteraceae & $\begin{array}{l}\text { Flower } \\
\text { and leaf }\end{array}$ & $\begin{array}{l}\text { Leaves are used for fever, flue, cough, asthma, digestive troubles, piles, } \\
\text { diabetes, urinary diseases, male sexual diseases, gynecological } \\
\text { diseases, joints pain/rheumatic pains and inflammation, ear diseases, } \\
\text { tooth problems, cuts and wounds, skin diseases, cooling agents and } \\
\text { miscellaneous uses. }\end{array}$ \\
\hline 34 & Crassula sp. & Crassulaceae & - & Ornamental plant. \\
\hline 35 & $\begin{array}{l}\text { Crossandra } \\
\text { infundibuliformis }\end{array}$ & Acanthaceae & $\begin{array}{l}\text { Leaf and } \\
\text { latex }\end{array}$ & $\begin{array}{l}\text { In the treatment of infectious diseases while simultaneously mitigating } \\
\text { many of the side effects. }\end{array}$ \\
\hline 36 & Cucumis реро & Cucurbitaceae & $\begin{array}{l}\text { Leaf, fruit } \\
\text { and seed. }\end{array}$ & $\begin{array}{l}\text { Seeds are used as a diuretic. Leaves are used as a painkiller, a } \\
\text { treatment for nausea, and a boost to haemoglobin content of the blood. } \\
\text { The fruit is used for cooling and astringent to the bowels, increases } \\
\text { appetite, cures leprosy and purifies the blood. }\end{array}$ \\
\hline 37 & Curcuma longa & Zingiberaceae & Rhizome & $\begin{array}{l}\text { A fresh juice is commonly used in many skin conditions, including } \\
\text { eczema, chicken pox, shingles, allergy and scabies. The active } \\
\text { compound curcumin have antiinflammatory, antioxidant, antitumour, } \\
\text { antibacterial and antiviral activities. }\end{array}$ \\
\hline 38 & Calotropis gigantea & Asclepiadaceae & $\begin{array}{l}\text { Leaf and } \\
\text { latex }\end{array}$ & $\begin{array}{l}\text { The powdered root is used to treat bronchitis, asthma, leprosy, } \\
\text { eczema, elephantiasis while the latex is used to treat vertigo, baldness, } \\
\text { hair loss, toothache, intermittent fevers, rheumatoid/joint swellings } \\
\text { and paralysis. }\end{array}$ \\
\hline 39 & Carica papaya & Caricaceae & $\begin{array}{l}\text { Leaf, fruit } \\
\text { and root }\end{array}$ & $\begin{array}{l}\text { It increase appetite, ease menstrual pain, meat tenderizer and relieve } \\
\text { nausea }\end{array}$ \\
\hline 40 & $\begin{array}{l}\text { Coriandrum } \\
\text { sativum }\end{array}$ & Apiaceae & $\begin{array}{l}\text { Seed, root } \\
\text { and leaf }\end{array}$ & $\begin{array}{l}\text { The seeds were included in a host of prescriptions for fever, diarrhoea, } \\
\text { vomiting, indigestion as in stomach and carminative. Leaves are given } \\
\text { for biliousness, intestinal irritations, heartburn, thirst and nausea. } \\
\text { Volatile oil is carminative. }\end{array}$ \\
\hline 41 & Citrus lemon & Rutaceae & $\begin{array}{l}\text { Fruit and } \\
\text { leaf }\end{array}$ & $\begin{array}{l}\text { It has also been found useful in the treatment of hepatobiliar, dyski- } \\
\text { nesia, oxiurasis, varicose veins, haemorrhoids, phlebitis and } \\
\text { urolithiasis. }\end{array}$ \\
\hline 42 & $\begin{array}{l}\text { Cardiospermum } \\
\text { halicacabum }\end{array}$ & Sapindaceae & $\begin{array}{l}\text { Leaf and } \\
\text { fruit }\end{array}$ & $\begin{array}{l}\text { The tender, young shoots are used as a diuretic, stomachic and } \\
\text { rubefacient. It is used in rheumatism, lumbago, nervous diseases and } \\
\text { as a demulcent in arthritis and in dropsy. }\end{array}$ \\
\hline 43 & Cycas siamensis & Cycadaceae & - & Ornamental plant. \\
\hline 44 & Dracaena sp. & Asparagaceae & Fruit & The fruits are used in the treatment of malarial and intestinal worms. \\
\hline 45 & Duranta repens & Verbenaceae & $\begin{array}{l}\text { Leaf and } \\
\text { fruit }\end{array}$ & $\begin{array}{l}\text { The roots are stimulant for indolent ulcer. Different parts of the carrot } \\
\text { have been used in medicine for the treatment of kidney dysfunction, } \\
\text { asthma, dropsy, inflammation, leprosy, worm troubles, etc. }\end{array}$ \\
\hline 46 & Damascus carota & Apiaceae & $\begin{array}{l}\text { Leaf and } \\
\text { latex }\end{array}$ & $\begin{array}{l}\text { The latex for a depilatory, pain relief, antibacterial and emetic. } \\
\text { Remedies for skin, warts and toothache. Regarding safety and efficacy } \\
\text { in pregnancy and lactation is lacking }\end{array}$ \\
\hline 47 & Ficus benghalensis & Moraceae & Leaf & It is used for the treatment of skin diseases and enlargement of liver. \\
\hline 48 & F. benjamina & Moraceae & $\begin{array}{l}\text { Leaf, bark } \\
\text { and root }\end{array}$ & $\begin{array}{l}\text { The treatment of certain skin disorders, stomachic, hypotensive and } \\
\text { antidysentery. Leaf, bark and fruits are used as antimicrobial, } \\
\text { antitumor, antiinflammatory, antinociceptive, antipyretic and cytotoxic } \\
\text { activity. }\end{array}$ \\
\hline 49 & F. microspora & Moraceae & $\begin{array}{l}\text { Leaf and } \\
\text { bark }\end{array}$ & $\begin{array}{l}\text { It has been used for intestinal problems, wounds and respiratory } \\
\text { ailment. Oil is considered a relaxant in aroma therapy and in recent } \\
\text { years it is used as respiratory. }\end{array}$ \\
\hline 50 & $\begin{array}{l}\text { Geranium } \\
\text { domesticum }\end{array}$ & Geraniaceae & $\begin{array}{c}\text { Seed and } \\
\text { leaf }\end{array}$ & Ornamental plant. \\
\hline 51 & G. peltatum & Geraniaceae & Flower & $\begin{array}{l}\text { It is used to treat athlete's foot, skin lesions, rashes, insect bites, } \\
\text { nervous shock, inflammation, rheumatism, headache, asthma, and } \\
\text { dysentery. }\end{array}$ \\
\hline
\end{tabular}




\begin{tabular}{|c|c|c|c|c|}
\hline 52 & Grevillea robusta & Proteaceae & - & Ornamental plant. \\
\hline 53 & Hamelia patens & Rubiaceae & $\begin{array}{l}\text { Leaf and } \\
\text { flower }\end{array}$ & $\begin{array}{l}\text { It regulates menstruation and stimulate blood circulation. The flower } \\
\text { extract has been traditionally used for liver disorders, high blood } \\
\text { pressure and as an aphrodisiac. Young leaves and flowers are used in } \\
\text { case of headache. }\end{array}$ \\
\hline 54 & $\begin{array}{l}\text { Hibiscus } \\
\text { rosasinensis }\end{array}$ & Malvaceae & $\begin{array}{l}\text { Flower, } \\
\text { root and } \\
\text { leaf }\end{array}$ & They are used in antiinflammatory. \\
\hline 55 & H. mutabilis & Malvaceae & $\begin{array}{l}\text { Leaf, } \\
\text { flower and } \\
\text { seed }\end{array}$ & $\begin{array}{l}\text { The leaves are diuretic, expectorant and stomachic. Decoction of the } \\
\text { flowers is used for ophthalmic and stomachic. It is also used in the } \\
\text { treatment of itch and other skin diseases. }\end{array}$ \\
\hline 56 & H. syriacus & Malvaceae & $\begin{array}{l}\text { Leaf and } \\
\text { flower }\end{array}$ & It cures skin diseases. \\
\hline 57 & $\begin{array}{l}\text { Hydrangea } \\
\text { macrophylla }\end{array}$ & Hydrangeaceae & - & Ornamental plant. \\
\hline 58 & $\begin{array}{l}\text { Inga } \\
\text { cyanometroides }\end{array}$ & Fabaceae & Leaf & $\begin{array}{l}\text { It is used for hepatic disorder, cancer, microbial infection, antioxidant, } \\
\text { pain, inflammation. The flowers were used for the treatment of cancer, } \\
\text { leucorrhoea, dysentery, dysmenorrhoea, haemoptysis and } \\
\text { hypertension. }\end{array}$ \\
\hline 59 & Ixora coccinea & Rubiaceae & $\begin{array}{l}\text { Leaf, root } \\
\text { and flower }\end{array}$ & $\begin{array}{l}\text { The leaves are used as an emetic in cases of poisoning. The roots are } \\
\text { bitter, acrid and are useful for external application in ringworm and } \\
\text { herpes infestations and are recommended for ophthalmopathy, } \\
\text { ulcerative stomatitis, leprosy, pruritus and wounds. }\end{array}$ \\
\hline 60 & $\begin{array}{l}\text { Jacquemontia } \\
\text { pentantha }\end{array}$ & Convolvulaceae & - & Ornamental plant. \\
\hline 61 & $\begin{array}{l}\text { Jasminum } \\
\text { angustifolium }\end{array}$ & Oleaceae & $\begin{array}{l}\text { Leaf and } \\
\text { root }\end{array}$ & $\begin{array}{l}\text { Leaves are used in the treatment of leprosy, skin disease, ulcers, } \\
\text { wounds and corns. }\end{array}$ \\
\hline 62 & J. grandiflorum & Oleaceae & $\begin{array}{l}\text { Leaf and } \\
\text { root }\end{array}$ & $\begin{array}{l}\text { Leaves are used in the treatment of leprosy, skin disease ulcers } \\
\text { wounds and corns. }\end{array}$ \\
\hline 63 & Jatropha peltata & Oleaceae & $\begin{array}{l}\text { Leaf, } \\
\text { flower and } \\
\text { root }\end{array}$ & $\begin{array}{l}\text { The plant is used for cooling, skin disorders, leprosy, ulcers, in cases of } \\
\text { insanity, weakness of sight and affections of mouth and opium for } \\
\text { gangrenous ulcers of the gums. }\end{array}$ \\
\hline 64 & Jasminum sambac & Euphorbiaceae & Leaf & $\begin{array}{l}\text { It is used to treat gastric ulcer and allied stomach ailments and } \\
\text { malarial disease. }\end{array}$ \\
\hline 65 & $\begin{array}{l}\text { Kalanchoe } \\
\text { fentchokoi }\end{array}$ & Rubiaceae & - & Ornamental plant. \\
\hline 66 & Knoxia sp. & Juncaceae & - & Ornamental plant. \\
\hline 67 & Lablab purpureus & Fabaceae & Leaf & $\begin{array}{l}\text { It has been used an antioxidant, anticancer, antiviral and } \\
\text { antiinflammatory activities. }\end{array}$ \\
\hline 68 & Lantana viscose & Verbenaceae & Leaf & $\begin{array}{l}\text { The leaves are used to treat rheumatism, gout, hemorrhoids, fractures } \\
\text { and snake bites and also in the treatments of anesthetic and smooth } \\
\text { muscle relaxant antidiabetic, antiulcer, antiinflammatory and } \\
\text { antimicrobial. }\end{array}$ \\
\hline 69 & Lawsonia inermis & Myrtaceae & $\begin{array}{l}\text { Stem bark, } \\
\text { root and } \\
\text { leaf }\end{array}$ & $\begin{array}{l}\text { Henna leaves, flowers, seeds, stem bark and roots are used in } \\
\text { traditional medicine to treat a variety of ailments as rheumatoid } \\
\text { arthritis, headache, ulcers, diarrheoa, leprosy fever, leucorrhoea, } \\
\text { diabetes, cardiac disease, hepatoprotective and colouring agent. }\end{array}$ \\
\hline 70 & Madhuca longifolia & Sapotaceae & $\begin{array}{l}\text { Fruit and } \\
\quad \text { latex }\end{array}$ & $\begin{array}{l}\text { The flowers are used as tonic, analgesic and diuretic, used as cooling } \\
\text { agent, tonic, aphrodisiac, astringent, demulcent and for the treatment } \\
\text { of helminthes, acute and chronic tonsillitis, bronchitis. Madhuka can be } \\
\text { used to treat gastro intestinal ulcers. }\end{array}$ \\
\hline 71 & Mangifera indica & Anacardiaceae & $\begin{array}{l}\text { Fruit and } \\
\quad \text { leaf }\end{array}$ & $\begin{array}{l}\text { Fruit is proposed as nutritional supplement (antioxidant) and an } \\
\text { antiinflammatory, analgesic and immunomodulatory treatment to } \\
\text { prevent disease progress or increase the patient's quality of life in } \\
\text { gastric and dermatological disorders, AIDS, cancer and asthma. Root } \\
\text { bark is a bitter aromatic and used for diarrhea and leucorrhea. }\end{array}$ \\
\hline 72 & $\begin{array}{l}\text { Miranda } \\
\text { leucophyllum }\end{array}$ & Scrophulariaceae & - & Ornamental plant. \\
\hline 73 & $\begin{array}{l}\text { Momordica } \\
\text { charantia }\end{array}$ & Cucurbitaceae & $\begin{array}{l}\text { Leaf, Fruit } \\
\text { and root }\end{array}$ & $\begin{array}{l}\text { Leaves are used for ulcers and as a bitter digestive aid for intestinal } \\
\text { gas, bloating, stomachache and sluggish digestion. Fruit pulp, leaf juice } \\
\text { and seeds are used for antihelimintic. Leaf act as galactogogue. Roots } \\
\text { are used for astringent. }\end{array}$ \\
\hline 74 & Murraya paniculata & Moringaceae & $\begin{array}{l}\text { Leaf and } \\
\text { fruit }\end{array}$ & $\begin{array}{l}\text { The leaves and fruit possesses antiinflammatory, antimicrobial, } \\
\text { antioxidant and anticancer activity and also used for cardiovascular, } \\
\text { hepatoprotective, antiulcer, diuretic, antiurolithiatic and antihelmintic } \\
\text { activities. }\end{array}$ \\
\hline 75 & Musa paradisiaca & Rutaceae & $\begin{array}{l}\text { Leaf and } \\
\text { root bark }\end{array}$ & $\begin{array}{l}\text { Their root bark is used as an anodyne or local anesthetic for the } \\
\text { treatment of gout, contusion and bone ache. }\end{array}$ \\
\hline 76 & Moringa oleofera & Musaceae & $\begin{array}{r}\text { Whole } \\
\text { plant }\end{array}$ & $\begin{array}{l}\text { Unripe bananas and plantain fruits are astringent, and used to treat } \\
\text { diarrhea. The leaves are used for cough and bronchitis. The roots can }\end{array}$ \\
\hline
\end{tabular}




\begin{tabular}{|c|c|c|c|c|}
\hline & & & & $\begin{array}{l}\text { arrest hemoptysis and posses strongly astringent and anthelmintic } \\
\text { properties. }\end{array}$ \\
\hline 77 & Nephrolepis sp. & Nephrolepidaceae & - & Ornamental plant. \\
\hline 78 & N. tuberosa & Nephrolepidaceae & $\begin{array}{l}\text { Whole } \\
\text { plant }\end{array}$ & $\begin{array}{l}\text { Used as healing agents in inflammation, leucorrhoea, piles and as } \\
\text { antidote. It possesses antiviral, antibacteral, antiparasitic, } \\
\text { antiinflammatory, antiulcer and antioxidant activity and used as } \\
\text { diuretic. }\end{array}$ \\
\hline 79 & Nerium oleander & Apocynaceae & $\begin{array}{l}\text { Flower } \\
\text { and leaf }\end{array}$ & $\begin{array}{l}\text { The flowers are used as blood purifier and also used in the treatment } \\
\text { of jaundice, diabetes, cancer, inflammation and eye disorders. }\end{array}$ \\
\hline 80 & Ocimum basilicum & Lamiaceae & Leaf & It cures cold, cough and having high medicinal value. \\
\hline 81 & Oxalis radicosa & Oxalidaceae & - & The leaves cure dysentery, diarrhea and skin disease \\
\hline 82 & O. corniculata & Oxalidaceae & $\begin{array}{l}\text { Leaf and } \\
\text { flower }\end{array}$ & $\begin{array}{l}\text { It is used to cure blood pressure high cholesterol hardening of the } \\
\text { arteries atherosclerosis, pain and swelling of the pancreas and } \\
\text { pancreatitis cancer. Leaves are applied to sore eyes. }\end{array}$ \\
\hline 83 & Phyllanthus emblica & Euphorbiaceae & $\begin{array}{c}\text { Fruit and } \\
\quad \text { leaf }\end{array}$ & $\begin{array}{l}\text { Juice of the plant is useful in eye and ear diseases. Leaves are } \\
\text { considered antiseptic, antitubercular, antidysenteric and anthelmintic } \\
\text { and also used in eczema, leprosy, piles, ulcers, syphilis, cough and } \\
\text { asthma. It is also used as a poultice in hemorrhoid. }\end{array}$ \\
\hline 84 & Pistia stratiotes & Araceae & Leaf & $\begin{array}{l}\text { The root juice is used for gastric acidity before each meal for a weak. } \\
\text { The latex has been used for the treatment of itches, swellings and }\end{array}$ \\
\hline 85 & $\begin{array}{l}\text { Plumbago } \\
\text { auriculata }\end{array}$ & Plumbaginaceae & $\begin{array}{l}\text { Root and } \\
\text { leaf }\end{array}$ & $\begin{array}{l}\text { fevers, inflammations, arthritis and constipation. In the Guinas } \\
\text { medicines are produced from root and bark and used for the treatment } \\
\text { of skin eruptions and abscesses, dysentery, herpes, syphilis, cough and } \\
\text { as a purgative. }\end{array}$ \\
\hline 86 & Plumeria rubra & Apocynaceae & $\begin{array}{l}\text { Root, bark } \\
\text { and latex }\end{array}$ & $\begin{array}{l}\text { The fruits are used in the treatment and prevention of cancer, } \\
\text { cardiovascular disease, diabetes, dental problems, erectile dysfunction, } \\
\text { bacterial infections, antibiotic resistance and ultraviolet radiation } \\
\text { induced skin damage. }\end{array}$ \\
\hline 87 & Punica granatum & Punicaceae & Fruit & $\begin{array}{l}\text { Fruits are used in the treatment of diabetes and kidney stone } \\
\text { problems, arteriosclerosis, diabetic nephropathy, diabetic retinopathy } \\
\text { in addition to the control of blood glucose level. }\end{array}$ \\
\hline 88 & Piper betle & Piperaceae & Leaf & It cures cold and cough. \\
\hline 89 & $\begin{array}{l}\text { Ravenala } \\
\text { madagascariensis } \\
\text { Robinia }\end{array}$ & Strelitziaceae & Leaf & $\begin{array}{l}\text { Leaves are used for metrorrhagia, hemoptysis, large intestine } \\
\text { hemorrhage, rheumatic arthritis and gynecologic disease. }\end{array}$ \\
\hline 90 & pseudoacacia & Fabaceae & Leaf & Leaves are used to cure skin diseases and scabies. \\
\hline 91 & Tiarella grandiflora & Brassicaceae & - & Ornamental plant. \\
\hline 92 & Rosa sp & Rosaceae & Flower & $\begin{array}{l}\text { It has been used for maintaining health, boosting immune system } \\
\text { function and remission of cancer. }\end{array}$ \\
\hline 93 & Salvinia officinalis & Lamiaceae & Leaf & $\begin{array}{l}\text { The leaf sap is applied directly to sores, cuts and grazes and it include } \\
\text { treatment for abdominal pains, ear ache, diarrhea and hemorrhoids. }\end{array}$ \\
\hline 94 & $\begin{array}{l}\text { Sansevieria } \\
\text { roxburghiana }\end{array}$ & Asparagaceae & Flower & $\begin{array}{l}\text { Paste of leaves can be applied to relieve pains. Seeds act as expectorant } \\
\text { in cough and asthma. The roots are expectorant and diuretic, useful in } \\
\text { the treatment of catarrhal fever, coughs, asthma and chest pain. }\end{array}$ \\
\hline 95 & $\begin{array}{l}\text { Scindapsus } \\
\text { variegata }\end{array}$ & Araceae & - & Ornamental plant. \\
\hline 96 & S. melongena & Solanaceae & $\begin{array}{l}\text { Fruit and } \\
\quad \text { leaf }\end{array}$ & $\begin{array}{l}\text { Decoction of leaf is used to cure diabetes, leprosy, gonorrhea, cholera, } \\
\text { bronchits, dysentery, asthenia and haemorrhoids. }\end{array}$ \\
\hline 97 & S. lycopersicum . & Solanaceae & Fruit & $\begin{array}{l}\text { It is used in women related problems, such as leucorrhoea, } \\
\text { menorrhagia, dysfunctional uterine bleeding and bleeding } \\
\text { hemorrhoids. }\end{array}$ \\
\hline 98 & Saraca indica & Caesalpiniaceae & Leaf & $\begin{array}{l}\text { It cures the diseases of eyes cold conjunctivitis, cough, bleeding piles } \\
\text { and ulcers bronchitis. }\end{array}$ \\
\hline 99 & Tagetes erecta & Asteraceae & Flower & It is used for anticancer. \\
\hline 100 & $\begin{array}{l}\text { Tradescantia } \\
\text { discolor }\end{array}$ & Commelinaceae & - & Ornamental plant. \\
\hline 101 & Thuja occidentalis & Cupressaceae & Leaf & $\begin{array}{l}\text { The essential oil within the plant has been used for cleansers, } \\
\text { disinfectants, hair reparations, insecticides, liniment, room sprays and } \\
\text { soft soaps. }\end{array}$ \\
\hline 102 & T. mysorensis & Acanthaceae & - & Ornamental plant. \\
\hline 103 & $\begin{array}{l}\text { Tabernaemontana } \\
\text { divaricata }\end{array}$ & Apocynaceae & Leaf & Ornamental plant. \\
\hline 104 & Tecoma grandis & Bignoniaceae & Flower & $\begin{array}{l}\text { The leaves were widely used as medicine for dermatosis and hepatitis. } \\
\text { Leaves and fruits have anticancer, antioxidant, anti HIV, } \\
\text { antiinflammatory, anti diabetic and hepatoprotective activities. }\end{array}$ \\
\hline 105 & Terminalia catappa & Combretaceae & Fruit & $\begin{array}{l}\text { It has unique property of preventing the growth of cancerous cells, and } \\
\text { being used in the treatment of breast and ovarian cancer. }\end{array}$ \\
\hline 106 & Taxus wallichiana & Taxaceae & Leaf and & The stem bark is used as a anticancer. This species is also used as fuel \\
\hline
\end{tabular}




\begin{tabular}{lllcl}
\hline 107 & $\begin{array}{l}\text { Ursinia cerevisiae } \\
\text { Zepnyranthes }\end{array}$ & Asteraceae & bark & wood by the local communities. \\
108 & $\begin{array}{l}\text { Amaryllidaceae } \\
\text { carinata }\end{array}$ & Flower & Osed for the treatment of vermifuge and astringent. \\
109 & Zinnia grandiflora & Asteraceae & - & Ornamental plant. \\
\hline
\end{tabular}

Among the 109 species enlisted in the studied home gardens, the economic importance including the medicinal uses of the various plant species present in the sampled home gardens is depicted in Table 2. In the account of 109 species, 86 (78.90\%) were recognized as medicinally important and $23(21.10 \%)$ as ornamentals. The medicinal uses of the plant species are multidimensional. A greater number of 20 species are used to treat skin diseases and a sizeable number of 12 species are precribed for anticancer activities. In addition, 11 species have been known for antidiabetic properties and 2 species each for gynecological disorders and for the treatment of dysentery respectively. Interestingly it has been noted that the 2 species namely Tecoma grandis and Mangifera indica are having antiviral property suggested for AIDS patients. The results of present study exhibited a considerable array of plant species in the home gardens of Coimbatore city with different medicinal and other economic uses. Presently many home gardens show a shift from subsistence oriented agriculture to market (Peyre et al., 2006).

\section{CONCLUSION}

In conclusion, home gardens in Coimbatore city appear to be supplementary agricultural production systems, which are managed and controlled by household members. Involvement of family members in home gardening activities empowers them to become self-reliant and simultaneously making a contribution to household food security. In addition, the home gardens can save species from the risk of extinction and thus, home gardens can be considered as a tool for conservation of medicinal plants.

\section{ACKNOWLEDGEMENT}

The authors graciously acknowledge Dr.M. Aruchami Research Foundation for providing financial support to carry out this work.

\section{REFERENCES}

Abdoellah, O.S. (1990). Home gardens in the Java and their future development In: K Landaeurand $\mathrm{M}$. Brazil (eds.) Tropical Home gardens. United Nations University Press Tokyo, Japan. 69-79.

Ahmedullah, M. and M.P. Nayar, (1987). Endemic plants of the Indian Region. Vol. 1. Botanical Survey of India, Howrah.
Buchmann, C. (2009). Cuban home gardens and their role in socio ecological resilience. Human Ecol. 37: 705-721.

Eliotcoleman, (2000). A Gardens for all seasons, St6.yahoo.com/cooks garden.

Fernandez, E.C.M. and P.K.R Nair, (1986). An evaluation of the structure and functions of tropical Home gardens. Agroforestry systems 2: 279-310.

Hollingsworth, P.M., I.K. Dawson, W.P. GoodallCopestake, J.E. Richardson, J.C. Weber, C. Sotelo and R.T. Pennington, (2005). Do farmers reduce genetic diversity when they domesticate tropical trees? A case study from Amazonian. Mol Ecol. 14: 497-501.

Kabir, M.E and E.L. Webb, (2008). House hold and homegardens characteristics in south western Bangladesh. Agro. syst. 24: 203-213.

Kumar, B.M and P.K. Nair, (2004). The enigma of tropical home gardens. Agro. Syst. 61:135-152.

Kumar, B.M., S.J. George and S. Chinnamani, (1994). Diversity, structure and standing stock wood in the home gardens of Kerala Peninsular India. Agro. syst. 25: 243-262.

Lengkeek, A.G., A.M. Mwangi, C.A.C. Agufa, J.O. Ahenda, I.K. Dawson, (2006). Comparing genetic diversity in agroforestry systems with natural forest: a case study of the important timber tree Vitex fischeri in central Kenya. Agro. Syst. 67: 293-300.

Miller, A.J and B.A. Schaal, (2006). Domestication and the distribution of genetic variation in wild and cultivated populations of the Mesomerican fruit tree, Spondias purpurea L. (Anacardiaceae). Mol. Ecol. 15: 1467 -1480.

Pandey, C.B., R.B. Rai, L. Singh and A.K. Singh, (2006). Home gardens of Anadaman and Nicobar, India. Agricultural systems (press).

Peyre A., A. Guidal, K.F. Wiersum and F. Bongers, (2006). Dynamics of home garden. Structure and function in Kerala India Agro. Syst. 66: 101.

Raheem, D.C., F. Naggs, R.C. Preece, Y. Mapatuna, L. Kariyaswam, P. Eggleon, (2008). Structure and conservation of Sri lankan land -snail assemblages in fragmented lowlands rain forest and village home gardens. J. Appl. Ecol. 45: 1019 -1028.

Rico Gray.V., A. Chemas and S. Mandujano, (1991). Uses of tropical deciduous forest species by the Yucataean Maya, Agro. Syst. 14: 149-161.

Rowe, C.W. (2009). Kitchen gardens in Tajikistahan: The economic and cultural importance of smallscale private property in a post-soviet society. Human Ecol. 37: 691-703.

Saha, S.K., P.K.R. Nair, V.D. Nair and B.M. Kumar, (2009). Soil carbon stock in relation to plant diversity of home gardens in Kerala, India. Agro. syst. 76: 53-65 